\title{
The DNA of prophetic speech
}

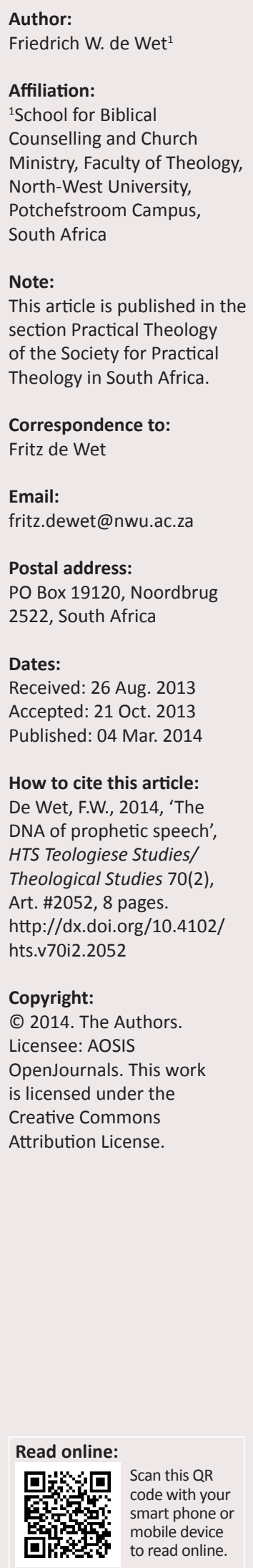

Having to speak words that can potentially abuse the divine connotation of prophetic speech for giving authority to the own manipulative intent poses a daunting challenge to preachers. The metaphorical images triggered by 'DNA' and 'genetic engineering' are deployed in illustrating the ambivalent position in which a prophetic preacher finds himself or herself; ambivalence between anticipation of regeneration at the deepest level of humanity on the one hand, and disquiet about the possibility of forcing a human being against his or her will into meeting certain prescribed expectations on the other hand. In reflecting on possible responses to this ambivalence, the theological positions of two prolific scholars in the research field of Homiletics, Gijs D.J. Dingemans and Charles L. Campbell, are critically considered from the point of view of the relationship between Christology and Pneumatology. In reflecting on theological markers for a sensible response, the author argues for a pneumatology in which the work of the Spirit consists of grafting the very DNA of our humanity and all its faculties into Christ, the only One who can open up the true life that is intended for humanity by divine grace. It will be in the very genes of a prophet to speak graceful words, because the prophet will have seen the wonder of the working of divine grace in his or her own life and will have embraced it willingly and joyfully.

\section{The trouble with prophetic speech}

Prophetic speech finds itself in troubling times.

A prophet is called to engage people - who find themselves anchored in this world and its dominant systems - in considering God's vision for their lives and their societies. Through the actions of a prophet, as Philip Wogamen (1998:4) reasons, people are supposed to have a window into the reality of God and how the reality of God can shape and direct their existence. It is expected that people will be drawn into the reality of God by authentic prophetic speech, in such a way that they cannot longer be content with conventional wisdom and superficial existence ${ }^{1}$. From the contemporary situation preachers find themselves in - at least in Western culture - it seems as if speaking a word that claims to be 'prophetic' has become controversial. The hesitancy to speak a prophetic word and rather electing to stay on safe ground by speaking an encouraging word to help middle class people cope with life (cf. Buttrick 2007:9), has led observers like Marvin McMickle (2006:8) to ask the inevitable question: 'Where have all the prophets gone?' Instead of speaking the truth to powers that are opposed to the full righteousness of the kingdom of heaven, preachers become pre-occupied with political correctness and selfprotecting modes of ministry.

Perhaps the most noticeable manifestation of the tension field preachers find themselves in, has to do with fear of speaking a word that can potentially abuse the divine connotation of prophetic speech for giving authority to the own manipulative intent; it has to do with the fear of forcing people against their will into a certain system of thinking that is pre-occupied with keeping the status quo intact and in the process marginalising others ${ }^{2}$.

The main argument in this article is that the person called to prophetic speech needs to become conscious of the workings of change at the deepest level of humanity to find a liberating base for speaking a prophetic word. Preachers need to consider the way God's regenerating grace changes their own hearts before they can speak a word that calls for change at the deepest level in the lives of their listeners and the social context they find themselves in.

In exploring the problem field, the following outline will be followed:

- An explanation of the choice of 'DNA' and 'genetic engineering' as appropriate metaphors

1.For references to the dynamics of and challenges faced by prophetic speech in contemporary culture, the following sources can be consulted: Brueggemann, W., 2012, The practice of prophetic imagination - preaching an emancipating word, Fortress, Minneapolis; Tubbs Tisdale, L., 2010, Prophetic preaching - A pastoral approach, Westminster John Knox Press, Louisville.

2.For a discussion of the impact of the post-apartheid dispensation on the minds of previously advantaged preachers, see De Klerk, B.J., De Wet, F.W. \& Letšosa, R.S., 2009, 'Exposure to vulnerability as a new opportunity in preaching the gospel to vulnerable people', Practical Theology in South Africa 24(1), 48-71. For the impact of change on the minds of American people who experience that their previously advantaged position is threatened, see Brueggemann, W., 1997, Cadences of home: Preaching among exiles, Westminster John Knox Press, Louisville. 
for describing the dynamics at work in the problem field surrounding prophetic speech and human change.

- The ambivalence between joy over God's regenerative grace and concern over power abuse in the praxis of prophetic speech.

- Responding to the ambivalence: perspectives from theoretical reflection on the relationship between Christology and Pneumatology.

\section{'DNA' and 'genetic engineering' as metaphors for the role op prophetic speech in divine regeneration}

In this section a case is made for the appropriateness of 'DNA' and 'genetic engineering' as metaphors for a contemporary description of the dynamics involved in the relationship between divine action and human action in the process of regeneration.

In 1953 Francis Crick and James Watson described how the strands of the DNA molecule show themselves to be arranged in a double helix, in such a way that DNA can firstly, replicate itself faithfully, and, secondly carry information ${ }^{3}$.

Along the DNA strand, as Ronald Cole-Turner (1993:14) explains, chemical patterns act like the letters of a code, conveying genetic instructions for the building of the cell. Scientists learned how certain chemicals found in the cell can cut a DNA chain. After isolating plasmids, or small circles of DNA in bacterial cells, they cut the plasmid DNA circle with a restriction enzyme, making a strand. Then they attached 'foreign' DNA - obtained from another kind of organism - to one end of the plasmid DNA. The plasmid DNA was reconnected to form a circle and then reinserted into the bacteria cell, which would recommence reproduction. Each time the cell divided, the plasmid replicated or copied itself, together with the inserted foreign DNA. DNA from two sources had been joined, and it produced copies of itself in its modified, hybrid form.

The process involved in this recombinant DNA technology became to be known as 'genetic engineering'. Since its inception in the early 1970s, genetic engineering has been used to produce a variety of human proteins, including growth hormone, insulin, and interferon, in bacteria. Although still far from perfect, genetic engineering may, in future, become applicable to the creation of more complex organisms, offering the possibility of controlling and eliminating genetic disorders and malformations in humans (Cole-Turner 1993:14; cf. Rheeder \& Vorster 2006:134, 147).

Earlier technologies, as Cole-Turner (1993:8) points out, altered nature primarily by altering environments outside

\footnotetext{
3.Several types of nucleic acid are known to contribute to the basic building blocks of organic life. The type found in chromosomes is called deoxyribonucleic acid,
generally abbreviated to DNA. In 1953, work by Francis Crick, Rosalind Franklin, generally abbreviated to DNA. In 1953, work by Francis Crick, Rosalind Franklin,
James Watson and Maurice Wilkins lead to the determination, by James Watson and Francis Crick, of the structure of DNA as a double helix; a double-stranded nucleic acid that contains the genetic information (blueprint') for cell growth, division and function. For further reading, see Reiss, M.J. \& Straughan, R., 1996, Improving Nature? The science and ethics of genetic engineering, University Press, Cambridge, pp. 13-25.
}

living things. Genetic engineering will change nature by altering the genetic arrangement inside living things.

The ethical implications of this technology are far-reaching. Michael Sandel (2009) discusses the promise as well as the predicament presented by breakthroughs in genetic research:

The promise is that we may soon be able to treat and prevent a host of debilitating diseases. The predicament is that our newfound genetic knowledge may also enable us to manipulate our own nature- to enhance our muscles, memories, and moods; to choose the sex, height, and other genetic traits of our children ... ; [ to improve our physical and cognitive capacities; to make ourselves better than well]. (Sandel 2009:6, 7; cf. Rheeder \& Vorster 2006:132, 139)

Sandel (2009) reminds us of the unease with which we speak about the ethical implications of genetic engineering:

One cause for our unease seems to be questions regarding the
autonomy of a being whose genetic make-up has been tampered
with. Even favourable genetic enhancements (for example
predetermined musical talent or athletic prowess) would point
'designer children' towards particular life choices, impairing
their autonomy and violating their right and freedom to choose
their life plan for themselves. Another cause for our unease has to
do with the idea of using genetic engineering not merely to cure
a disease, but to reach beyond health in enhancing the physical
of cognitive capacity above the norm. The ethics of enhancement
will have to grapple with the questions regarding the natural
stance of human beings towards the given world they find
themselves in. Will a synthetically enhanced super-humanity
become estranged from the heart of its true humanity in the
sense that its organic relationship with its living environment
will be distorted? (pp. 6-7)

The metaphors of 'DNA' and 'genetic engineering' trigger ambivalent images in our minds: images of hope that promise regeneration of disintegrative, destructive and debilitating elements that are deeply rooted in the natural state of human life; but also disquieting images that trigger uneasiness over the idea of a kind of manipulative pre-determination that can force a human being against his or her will into meeting certain prescribed expectations without staying true to the full scope of his or her humanity in the process. This feeling of ambivalence gives a fair reflection of the position a theologian finds himself or herself in when reflecting on the role of prophetic speech in ministering the regenerative intent of God: On the one hand there is amazement and joyful anticipation over the prospect of a word that can be instrumental in a sort of renewal that does not only touch the surface of human life, but reaches to the very building blocks for weaving a new fabric of a regenerated humanity. On the other hand there is a disquieting concern over a word being abused in such a way that human beings are manipulated into a system that forces their lives into a certain direction and distorts what it entails to be truly human.

In the next section this ambivalence between joyful anticipation and disquieting concern will be explored by viewing the self-reflection regarding the ministry of renewal from the vantage point of reformed confessional thinking. 


\section{The ambivalence between joy over God's regenerative grace and concern over power abuse in the praxis of prophetic speech}

A Christian, living in confessional tradition that proceeds from a theocentric departure point in interpreting Scripture ${ }^{4}$, will see himself or herself as a person who has abundant reasons to be filled with amazement over the sheer scope and gracefulness of God's regenerative acts in our lives. God is praised and revered as the One who saves us through his grace by making us alive in Christ (Eph 2:4, 5); as the One who gives us a new mind by regenerating the imago Dei in us (Eph 4:23, 24); as the One who removes the heart of stone and gives us a heart of flesh (Ezk 11:19); as the One who makes us truly free (Gl 5:1).

Joyful reverence for the goodness and perfectness of God's regenerative acts, is clearly voiced in the confessional language of the Canons of Dordt ${ }^{5}$. The following two sections from chapters III and IV serve as good examples:

- 'But, when God performs his good pleasure in his elect, or works in them true conversion, he not only provides that the gospel should be outwardly preached to them, and that their mind should be powerfully illuminated by the Holy Spirit, that they may rightly understand, and judge what are the things of God; but He also by the efficacy of the same regenerating Spirit, penetrates into the innermost recesses of man, opens his closed heart, softens his obdurate heart, circumcises his uncircumcised heart, infuses new qualities into his will, makes that which had been dead alive, that which was evil good, that which had been unwilling willing, and from being refractory, obedient; and leads and strengthens it, that as a good tree, it may be able to bring forth the fruit of good works' (Canons of Dordt III \& IV, 11). ${ }^{6}$

- 'But in like manner, as by the fall man does not cease to be man, endowed with intellect and will, neither hath sin, which has pervaded the whole human race, taken away the nature of the human species, but it hath depraved and spiritually stained it; so even this divine grace of regeneration does not act upon men like stocks and trees, nor take away the proprieties (or properties, proprietates) of his will, or violently compel it while unwilling; but it spiritually quickens, (or vivifies,) heals, corrects, and sweetly, and at the same time powerfully

4. In the Reformed approach Scripture is viewed as a clear and authoritative revelation of God's encompassing acts in creation, redemption and consummation. Human actions are interpreted as actions anchored in and enabled by God's acts of grace in Christ. Therefore the five Solae of the Reformation (Sola scriptura, Soli Deo gloria, Sola gratia, Solo Christo, Sola fide) form the distinctive hermeneutical lenses for Reformed Scripture interpretation.

5.The Canons of Dordt originated at the Synod of Dordt (1618-1619) with the inten to formulate a judicial decision on the Five Articles of the 1610 Remonstrance that lay at the center of the Arminian controversy of that time. This document together with the Heidelberg Catechism and the Belgic Confession up till this day form the distinct triad of confessional standards (drie formulieren van eenigheit/three forms of unity) in Reformed churches of Dutch heritage (Sinnema, D.W., 2011b, 'The
Canons of Dordt: From judgment on Arminianism to Confessional Standard', in A Canons of Dordt: From judgment on Arminianism to Confessional Standard', in A. series in Church History, vol. 49), Koninklijke Brill NV, Leiden, p. 313.

6.The Canons of Dordt (1618-1619), transl. T. Scott (1993), Sprinkle Publications, Harrisburg. inclines it: so that whereas before it was wholly governed by the rebellion and resistance of the flesh, now, prompt and sincere obedience of the Spirit may begin to reign; in which the renewal of spiritual will and our liberty truly consist' (Canons of Dordt III \& IV, 16).?

The Canons express faith in the efficaciousness of divine grace by emphasising that the Word is not only outwardly preached to man (then the implication would have been that it is entirely up to man to decide what to do with the Word), but that the Spirit illuminates and sharpens the mind and regeneratively reaches the innermost parts of man in order to prepare a way for the Word. The synod's conceptualisation regarding the need for grace is formulated against the more optimistic view held by the Arminian anthropology; a view in which man is seen as being less weakened by sin and better equipped to acquire grace by his own natural abilities. The Synod argued that the human being is spiritually blind and dead, and is completely in need of regeneration from God's efficacious grace (cf. Goudriaan 2011:104).

The emphasis of the Canons, however, is not that grace is irresistible, but that grace is efficacious, regenerating human consciousness to a state in which it can perceive the true nature of the God-given grace. Grace is wholly ascribed to God. It is his good pleasure to give the new life he envisages for us, but also to prepare and liberate human consciousness towards willingly accepting this gift of grace. 'Wholly of God' does not imply irresistibility in a sense that would exclude the accordance of the (regenerated) human will from the process. Otherwise God would not be wholly God (wholly good) and man would not be wholly man (truly free). Irresistible force used by God on his people would be a violation of both the charity of God and the dignity of man. Salvation is wholly of God in the sense that he initiates and accomplishes it, but not in a compulsive sense that man is forced to accept it against his will (cf. Geisler 2010:140, 294, 303).

The abundant regenerative metaphors with which the efficacy of God's grace is described in the Canons speak of a language that radiates with amazement over the abundant goodness and pleasantness of God's way of doing things. He does not work with human beings in a dehumanising way - as if they were like dumb bricks and blocks to be forcefully moved (cf. Pleizier 2010:55). He spiritually quickens (vivificate), heals (sanat), corrects (corrigit), and sweetly, and at the same time powerfully bends (suaviter simul ac potenter flectit) the unregenerated will ${ }^{8}$. These words bear witness to an activity that is carefully and lovingly directed at nurturing human

\section{See footnote 6 .}

8.Latin text of Canons of Dordt, III and IV, 16: 'Sicuti vero per lapsum homo non desiit esse homo, intellectu et voluntate praeditus, nec peccatum, quod universum genus humanum pervasit, naturam generis humani sustulit, sed depravavit et spiritualiter occidit: ita etiam haec divina regenerationis gratia, non agit in hominibus tamquam truncis et stipitibus, nec voluntatem eiusque proprietates tollit, aut invitam violenter cogit, sed spiritualiter vivificate, sanat, corrigit, suaviter simul ac potenter flectit: cogit, sed spiritualiter vivificate, sanat, corrigit, suaviter simul ac potenter flectit: ut ubi antea plene dominabatur carnis rebellio et resistentia, nunc regnare incipia prompta ac sincera Spiritus obedientia; in quo vera et spiritualis nostrae voluntatis instauratio et libertas consistit. Qua ratione, nisi admirabilis ille omnis boni opifex nobiscum ageret, nulla spes esset homini surgendi e lapsu per liberum arbitrium per quod se, cum staret, praecipitavit in exitium' (Bakhuizen van den Brink, J.N., 1940, De Nederlandsche Belijdenisgeschriften, Uitgeversmaatschappij Holland, Amsterdam, p. 252). 
beings into a regenerated relationship with God and their living environment. Great care is taken to quicken what has become unresponsive, heal what has become degenerated, lovingly and powerfully bending open what has become inflexible. These metaphors used to describe the pleasantness of God's grace in restoring the flexibility and suppleness of the human will, echoes the way in which Calvin ([1559] 1991/1992) spoke of the regenerative work of God in us:

God begins his good work in us, therefore, by arousing love and desire and zeal for righteousness in our hearts; or, to speak more correctly, by bending, forming, and directing our hearts to righteousness. (Institutes [1559] 2.3.6)

Reverence for the completeness and tender-caring and noncoercive nature of God's efficacious grace seems to be a deeply rooted mind-set in the Calvinistic tradition that leads to a certain (glorifying) way of speaking about this grace.

But then there is another language that flows from the disquieted heart of an observer that sees other powers at work in spaces where the distinct character of God's grace is supposed to be present in its most clear form; language of lament over the unbearable reality that people, who are supposed to cherish and minister this divine grace, change it into something that is without grace and in the process violently distorting God's work. It is unbearable to think that prophetic speech can become an action that manipulates and threatens listeners into a rigid way of thinking; can become a word with which people are forcefully kept in line. The thinking behind this kind of approach has become disconnected with reverence for the holiness of the refined, loving power at work in divine regeneration. It has no heart for the human element of joyful acceptance and amazement over the fullness of human dignity opened up by this grace; people are forced into a system that cannot make the human mind and heart leap with joy.

When discussing Mary's experience of grace as it culminates in her Magnificat, Lundblad $(2001: 28,29)$ emphasises grace as starting point for transformation: Mary was not scared into transformation; nor was she threatened, coerced, or convinced of her own pridefullness as a trigger for transformation. Grace comes to Mary in her lowliness, in what the world could surely perceive as weakness. Mary's song of transformation is grounded in her deep assurance of God's grace, of God's deep regard for her. Throughout the history of Christian communities, Lundblad (2001:29) continues, other voices have often dominated: voices preaching transformation through fear of damnation or the conviction of people's sinful state. According to these voices, transformation cannot happen until a person repents. With Lundblad we can concur that, when the starting point is seen as grace, people will not be threatened into transformation by a threatening call to repentance, but will rather be liberated into endorsing repentance gladly as means of embracing the

\footnotetext{
9.For a discussion on the level of influence that the thinking of Johan Calvin had on the Canons of Dordt (probable influence on the issue of double predestination and possible influence on the themes of the universal call of the gospel, human depravity, efficacious grace, and perseverance) see Sinnema, D.W., 2011a, 'Calvin depravity, efficacious grace, and perseverance) see Sinnema, D.W., 2011a, 'Calvin
and the Canons of Dordt (1619)', Church History and Religious Culture 91(1/2), and the
}

vast dimensions of renewed human life opened up by God's grace.

Campbell and Cilliers (2012:63vv.) lament the creation of 'Iron Theology' as a search for power in the midst of uncertainties of a liminal space. The church often tends to mistake its structures and official theology as a final form of knowledge. It often positions itself in a dominating and controlling position within the networks of those who have power and others who are deemed to be without power. When this happens it marginalises, instead of siding with the marginalised. It is no longer the Kyrios of the cross that is served, but rather the iron-clad Kyrios of calculated power. In such a theology nothing is fluid; all is solid. The joy of the good news of the gospel is transformed into 'closed seriousness ${ }^{\prime 10}$.

The ambivalence of finding yourself in a position between joyful reverence for the gracefulness of God's work on the one hand and deep lament over the manifestation of 'Iron Theology' in the praxis of prophetic speech on the other hand, calls for a carefully weighed practical theological response ${ }^{11}$; a response that deals with the heart of the relationship between God's actions and human actions in his service; a response that - in other words - deals with the relationship between Christology (in the sense that it emphasises God's actions in Christ) and Pneumatology (in the sense that it involves our actions under guidance of the Spirit of Christ).

\section{Responding to the ambivalence: Perspectives from theoretical reflection on the relationship between Christology and Pneumatology}

The history of 'Iron Theology' is a long and sad one. Western Christianity has - to a certain extent - built up an unfortunate track record of abusing the gospel for own gain and position: Questions regarding the role played by elements of coercion during the Constantine Era, violent means deployed during the Crusades, cultural imperialism in missionary situations and marginalising and oppressive action in racial, gender and social equality issues are well-known examples (cf. Drake 1995:3; Dunch 2002:302; Latham 2011:234; Lundblad 2001:29).

These patterns in history haunt our minds and awaken a sense that all forms of power abuse and coercive action in the name of the kingdom of heaven simply cannot be tolerated, as it is totally inconsistent with the true nature of the Gospel entrusted to us. A longing is roused for a kind

10. With "closed seriousness' (a phrase originally used by Russian philosopher and literary theorist, Mikhail Bakhtin, in his work Rabelais and His World [1984]) Campbell and Cilliers (2012:42) refer to sense of control that demands and forbids seriousness' - on the other hand - is always ready to submit to death and renewal.

11. The theoretical reflection in this article is consciously undertaken from a practicaltheological vantage point. Practical-theological research is primarily concerned with the interaction between theological theory and praxis as it plays out in the with the interaction between theological theory and praxis as it plays out in the
action field of the relationship between God's actions and human actions in his service (De Ruijter 2005:21; Heitink 1999:18). 
of praxis that will respect elements such as human dignity and inclusive responsibility in the process of ministering God's regenerative work with its life-changing implications; a praxis that does not deviate from, but reflects and ministers the loving care and wisdom of God's grace right up to the prophetic DNA of the one entrusted with the ministry of this precious grace.

Sensing the need for reflection on the presence of the human element in the ministry of God's Word, noticeable shifts took place in the research field of Homiletics in the second part of the 20th century ${ }^{12}$. One of the clearest manifestations of these shifts amounts to a move from Christology (with its emphasis on what God has done for us in Christ) to Pneumatology (with its focus on human participation and responsibility in accordance with the work of the Spirit in us) (Douma 2000:49). Why was a kind of theology rooted in the Christological category deemed to be so problematic that a shift to the pneumatological category had to be considered? The heart of the problem seemingly had to do with a certain configuration of the Christological category in which the kerygmatic stance of the prophet (as the one who has to speak about what God has done for us in Christ) tends to speak a closed, absolutistic and monological word from on high; a word that is not sensitive to the heartbeat of human life in this world; a word that is not sensitive for the essential elements of what it constitutes to be truly human in its organic embeddedness in this world and in its free responsiveness.

In responding to the ambivalence between respect for the gracefulness of God's grace and concern over the manipulative element in human words that are supposed to minister this grace, two prolific authors in the research field of Homiletics, Gijs D.J. Dingemans ${ }^{13}$ and Charles L. Campbell ${ }^{14}$, place themselves at quite different positions on the spectrum of possible responses in the action field of Christology/Pneumatology. In critical dialogue with these two scholars, I will attempt to formulate initial theological markers for a responsible response.

\section{The response of Dingemans - A shift towards Pneuma-theology}

Dingemans (2005:162) mentions the important role played by Dutch scholar, Arnold A. van Ruler in defining the structural difference between Christological and Pneumatological approaches. Thinking that takes its point of departure in the Christological category tends to place the emphasis wholly on God's initiative and effective actions. An approach that takes its point of departure from the pneumatological

12.Shifts in Western culture regarding the function of authority as well as new attention for the responsive and interpretative presence of the human being in communicative action fields led to noticeable shifts in attention from a transcendent theocentric view to an immanent anthropocentric view and from the original biblical text to the contemporary situation of the listener (cf. Douma 2000:49; Immink 2008:12).

13.Gijs D.J. Dingemans is emeritus professor in Practical Theology at Rijksuniversiteit Groningen, Holland. He is renowned for the introduction of listener-involving preaching in the Dutch homiletic landscape with his seminal work, Als hoorder preaching in the Dutch homiletic landscape with his seminal work, Als
onder de hoorders. Een hermeneutische homiletiek, Kok, Kampen, 1991.

14.Charles L. Campbell is Professor of Homiletics at Duke Divinity School, USA. His thinking on power and authority is clearly expressed in, The Word before the powers - An ethic of preaching, Westminster John Knox Press, Louisville, 2002. category will shift the focus to the co-operative aspect. Christ saves you by replacing you. He does in your place what you could not do. The Spirit does not replace you, but empowers you and sets you to work. Through the working of the Spirit, the human being is placed on his feet and obtains an integral and responsive role in the process of responding to God's grace (Van Ruler 1969:175vv.; cf. Rebel 1981:193vv.). In theological views strongly dominated by the Christological category, God (in his heavenly holiness) and man (in the unworthiness of his sinful state) are placed sharply against each other. This culminates in a view on the function of the office in church as over and against the congregation and can potentially become a breeding ground for coercive and dominant actions. The Spirit, however, does not work in a dominating and coercive way, but rather in a serving and inviting way. The character of a prophetic word spoken in this pneumatological mode of thinking will become much more subtle and inviting. A future is visualised in which the church - temporarily at least - will serve a much more subdued role on the background as modest keepers of the Christian tradition (cf. Dingemans 2005:163).

In order to obtain an overview of Dingemans's response to the structural differences between the Christological and Pneumatological categories and the decidedly shift towards the pneumatological position in his thinking, two lines in his reasoning should be noted: firstly, his epistemological approach that moves from the future and its possibilities retrospectively back to the past; and secondly, his alignment with process theology:

Dingemans (2005:164) works with a retrospective epistemological approach: It is alone through the working of the Spirit that we can know the work of the Son and the Father. God is always a step ahead of us. He does not command and direct from the past, but he invites us by means of the voice of the Calling One ('de Stem van die de Roepende') to participate in his reign of possibilities: 'Hij is meer de potentia ("mogelijkheid"), dan de potestas ("almacht"), meer de oproeper van nieuwe kansen en wegen dan de machtige bewaarder en beschermer van het bestaande.' [He should be thought of more in terms of his potentia ('potentiality'), than in terms of his potestas ('almightiness'), more in terms of being the one that calls us to seek new changes and avenues, than being the mighty protector of the existing.] (Dingemans 2005:165).

Secondly, Dingemans $(2005: 121,124)$ confirms the influence of Alfred N. Whitehead's process-philosophical approach ${ }^{15}$ on his own thinking. Whitehead seeks his view on the organic unity between man and nature not in a static 'being' of existence that tends to categorise spheres of life over against each other. He rather emphasises the process of becoming: one element develops from the other and becomes what he is through the other. Their interdependency is a given. Whitehead associates God with the reign of possibilities from which a pulling force field emanates, perpetually

15.Whitehead, A.N., [1926] 1941, Process and reality: an essay in cosmology, Social Science Bookstore, New York. 
calling for new development. Dingemans (2005:125) also aligns himself with John B. Cobb Jr., an American theologian who - together with David R. Griffin - worked out the theological implications of Alfred Whitehead and Charles Hartshorne's philosophies and designed a process theology ${ }^{16}$. Cobb Jr. speaks of pan-en-theism as a form of imminent transcendence: God does not become one with the world, but also does not detach himself from the world. He is a hidden creative factor behind other factors in reality. He works like a coach that inspires his team with love - encouraging them from the front, rather than being like a producer that pulls the strings during a stage production - urging the actors on from behind.

Before we proceed to a critical assessment of the value of Dingemans's pneuma-theological approach in the quest for a sensible response to the ambivalence in which we find ourselves, we first need to consider the contribution that Charles Campbell makes in this regard. In his approach the attention is shifted back towards a new interpretation of the Christological category.

\section{The response of Campbell - The Christological category revisited}

Charles Campbell $(2002: 83,84)$ also finds it unbearable when the pulpit is abused for speaking manipulative words. In Campbell's environment, the abuse takes on several hidden and subtle forms: Even whilst resisting direct, interpersonal, physical violence, preaching often seems to participate in acts and systems of domination that involve harmful forms of psychological, spiritual, and even physical coercion that must be considered violent. At a subtler level, preachers have often used language in ways that support and sustain the Domination System ${ }^{17}$ - a system that deploys hierarchical imagery, often with indicated biblical support, to reinforce culture's divisions of people into dominant and subordinate. Rather than helping to set people free from captivity to the powers of the Domination System, the preacher simply reinforces that system in the relationship between preacher and parishioner.

Campbell (1997:xii), however, finds the reaction against speech that reinforces domination - as this reaction is manifested in the homiletical theories and writings of the last few decades - to be lacking in responsible theological reflection. Preachers have been advised to try inductive preaching, story preaching, dialogue sermons and homiletic plots (at the other end of the spectrum over against directive, absolutistic and closed speech). Whilst these new methods have been exciting for the moment, many preachers seem to sense that something is still missing.

16.Cobb, J.B. \& Griffin, D.R., 1976, Process theology - An introductory exposition Westminster Press, Philadelphia; cf. Müller $(2006: 81,82)$ for a reference to the introduction of process-theology in the context of South African Practical Theology.

17.Brueggemann (2012:4) describes the dominant narrative in American society as characterised by 'therapeutic, technological, consumerist militarism. It is as characterised by therapeutic, technological, consumerist militarism. It is committed to the notion of self-invention in the pursuit of self-sufficiency. Between [the] beginning in self-invention and [the] culmination in self-sufficiency, the narrative enjoins to competitive productivity, motivated by pervasive anxiet about having enough, or being enough, or being in control.' The 'dominan narrative is seldom lined out, rarely seen in its coherence, and hardly ever critiqued in its elemental claims'.
In formulating his critique against the kind of narrative approach that relativises the identity and presence of Jesus, Campbell $(1997: 196,200)$, utilises the post-liberal theory of Hans Frei ${ }^{18}$. In his discussion Campbell points out that Frei works with the idea of 'ascriptive logic' as a means of getting to the heart of the meaning of the Gospel narratives. It is maintained in Frei's ascriptive logic that Jesus should be as a living person with a unique and unsubstitutable identity. Jesus is not simply an example or metaphor of general human experience, but a unique agent enacting a unique mission; enacting God's way in this world. When the focus in a sermon shifts from the enacted intentions of Jesus to a mere reflection on what the implications of his inner life entails for our daily human experience, Jesus of Nazareth evaporates into thin air. The approach of the last decades with its anthropocentric emphasis on the act of human interpretation and the openness of metaphor, should ask itself up till what extent this reaction against directive preaching tends to minimise the active presence of Jesus during the sermon event and tends to lead to sermons that merely help middle class individuals in coping with life.

By voicing his critique against manipulative, absolutistic preaching (as it manifests in the domination-centred interpretation of the Christological category) as well as pointing out the severe limitations and one-sidedness in the reaction of the human experience-orientated approach (as it plays out in an anthropocentric interpretation of the pneumatological category), Campbell's response amounts to a call for a balanced view. And this return to a balanced view entails a return to a new interpretation of the Christological category, in which the bold words of Jesus and the embodiment of the reign of God associated with his presence are not marked by a character of coercion, but a certain kind of non-violent resistance against the powers that threaten to dominate and destroy our world. Campbell (2002:216) sees preaching as a form of discipleship shaped by the identity of Jesus Christ. It is not primarily storytelling or narrative artistry, but rather an act of moral obedience. Like Jesus, who embodied the reign of God and challenged the powers of the world, but refused to use violence or coercion in this effort, so the preacher, always at a distance, is engaged in this same non-violent resistance to powers in his or her preaching. Not only is the preacher's message shaped by the story of Jesus, but the very act of preaching itself is a performance of Scripture, an embodiment of God's reign after the pattern of Jesus.

In describing the non-manipulative nature of non-violent resistance, Campbell (2002:73) works with the perspectives of the French philosopher, Jacques Ellul ${ }^{19}$ on the relationship between the Word of God and human words. As Ellul argues, the very character of the Word as 'word' represents an alternative to the means and implements of violence. The

18.Together with his colleague, George Lindbeck, Hans Frei was instrumental in the development of the post-liberal theology of the so-called 'Yale School', representing
a fresh introduction of Karl Barth's theology in the USA. His book, The eclipse of a fresh introduction of Karl Barth's theology in the USA. His book, The eclipse of Biblical narrative: A study in eighteenth and nineteenth century hermeneutics (Yale
University Press, New Haven, 1974) made an important contribution to the postUniversity Press, New Haven, 1974)
critical literary reading of the Bible.

19.The humiliation of the Word, translated by J.M. Hanks from the original French La parole humiliée (Eerdmans, Grand Rapids, 1985, pp. 63-67). 
Word allows humans the freedom of decision, choice, and expression. The Word requires mutuality, the participation of the one speaking and listening; it refuses to make the 'other' - the hearer - into an object or a commodity, which is the character of the powers of technology and capitalism. Rather in always inviting response, the Word makes persons conscious of their opportunity to become subjects rather than objects.

\section{Initial theological markers for a responsible response}

In shifting from a dominating form of Christology to a synergistic Pneumatology, the focus seems to be on the potentiality that God's graceful calling places in our midst, rather than portraying God's grace in the actuality of its regeneration-effecting power. In my view, Dingemans's approach in his works overall, locates divine activity too much below the surface as a subtle part of a process, a process in which too much is expected from human responsibility and creativity. Disquiet about a forced ministration of God's grace in the way prophetic speech is actualised, can develop into an overreaction when words of a prophet are limited to a mere invitation to a dialogue about potentialities. To my mind, God's grace should be seen as an encompassing, efficacious, sola gratia activity that initiates renewal as well as leads it to fulfilment: Without God's grace opening the mind and softening the heart and making the will supple, we will not be able to joyfully embrace the start and the fulfilment of life his grace beckons us into.

Together with Campbell, I believe that the personal presence of Christ in the homiletical act is important. The act of preaching is indeed a performance of Scripture, an embodiment of God's reign after the pattern of Jesus. It is indeed a challenging act of non-violent resistance making persons conscious of their opportunity to become subjects in the ministration of God's reign rather than objects of an manipulative system.

But I would like to go one step further by anchoring Campbell's Christological ideas about the embodiment of God's reign after the pattern of Jesus in a Pneumatological category that incorporates organic faith - unity with Christ through the regenerative work of the Spirit. The Spirit - I believe grafts the very DNA of our humanity and all its faculties into Christ, the One who truly knows what is intended with and for humanity in its restored relationship with the Father (Col 1:15-20; Heb 2:14-18). The regenerative result of the faith union with Christ is that, our minds are renewed according to the beautiful mind of Christ - seeing the meaning of life in the glorious light of the goodwill and wisdom of the One who created it all and whose will it is to bring it all to consummation; our hearts are softened according to the heart of Christ - finding the innermost compassion with the brokenness of this world motivated by a deep-felt desire to minister the love with which God loved us; our faculties of intention are lovingly healed from its rigidness and self-centredness according to the will of
Christ; his desire to do the will of the Father and willingness to lay down his life for his own, becomes the heart of our willingness to become servants in the kingdom of God.

In other words, the act of the Spirit - in renewing us according to Christ - opens us to the fullness of what being human is intended to be in its most alert, intuitive, sensitive and liberated form. We are not coerced into something that is foreign to our humanity or curbs it in any way.

Only with the DNA of its humanity renewed according to Christ, will prophetic speech be able to radiate the light of God's truth in a way that will be not be dampening the spirits or oppressing the hearts or subduing the lives of the listeners to something that is far less than what God intended for them. As Ellul (1985) reasons, every human word is called on:

to express the Word of God, and there is a misuse of power, an abuse of words when this is not the case ... human language has an eternal reference from which it cannot escape without destroying itself [or stripping itself from meaning]. (p. 65)

It will be in the very genes of a prophet to speak graceful words; words that heal and liberate in the process of disclosure; words that energise in the process of criticising, because the prophet will have seen the wonder of the working of divine grace in his or her own life and will have embraced it willingly and joyfully.

\section{Acknowledgements Competing interests}

The author declares that he has no financial or personal relationship(s) that may have inappropriately influenced him in writing this article.

\section{References}

Bakhtin, M., 1984, Rabelais and his world, transl. H. Iwolsky, Indiana University Press, Bloomington.

Bakhuizen van den Brink, J.N., 1940, De Nederlandsche Belijdenisgeschriften, Uitgeversmaatschappij Holland, Amsterdam.

Brueggemann, W., 1997, Cadences of home: Preaching among exiles, Westminster John Knox Press, Louisville.

Brueggemann, W., 2012, The practice of prophetic imagination - Preaching an emancipating word, Fortress, Minneapolis.

Buttrick, D., 2007, 'Preaching today: The loss of a public voice', in M.P. Knowles (ed.) The folly of preaching - Models and methods, pp. 3-14, Eerdmans, Grand Rapids.

Calvyn, J., [1559] 1991/1992, Institusie van die Christelike godsdiens, vertl. H.W. Simpson, CJBF, Potchefstroom

Campbell, C.L., 1997, Preaching Jesus - New directions for Homiletics in Hans Frei's postliberal theology, Wipf \& Stock, Eugene.

Campbell, C.L., 2002, The Word before the powers - An ethic of preaching, Westminster John Knox Press, Louisville.

Campbell, C.L. \& Cilliers, J.H., 2012, Preaching fools - The Gospel as a rhetoric of folly, Baylor University Press, Waco.

Cobb, J.B. \& Griffin, D.R., 1976, Process theology - An introductory axposition, Westminster Press, Philadelphia.

Cole-Turner, R., 1993, The new Genesis - Theology and the genetic revolution, Westminster John Knox Press, Louisville.

De Klerk, B.J., De Wet, F.W. \& Letšosa, R.S., 2009, 'Exposure to vulnerability as a new opportunity in preaching the gospel to vulnerable people', Practical Theology in South Africa 24(1), 48-71.

De Ruijter, C.J., 2005, Meewerken met God - Ontwerp van een gereformeerde Praktische Theologie, Kok, Kampen.

Dingemans, G.D.J., 1991, Als hoorder onder de hoorders. Een hermeneutische homiletiek, Kok, Kampen. 
Dingemans, G.D.J., 2005, De stem van de Roepende - Pneumatheologie, Kok, Kampen. Douma, J., 2000, Veni Creator Spiritus: De meditatie en het preekproses, Kok, Kampen. Drake, H. A., 1995, 'Constantine and Consensus', Church History 64(1), 1-15. http:// dx.doi.org/10.2307/3168653

Dunch, R., 2002, 'Beyond cultural imperialism: Cultural theory, Christian missions, and global modernity', History and Theory 41(1), 301-325. http://dx.doi. org/10.1111/1468-2303.00208

Ellul, J., 1985, The humiliation of the Word, transl. J.M. Hanks, Eerdmans, Grand Rapids.

Frei, H., 1974, The eclipse of Biblical narrative: A study in eighteenth and nineteenth century hermeneutics, Yale University Press, New Haven.

Geisler, N.L., 2010, Chosen but free - A balanced view of God's sovereignty and free will, 3rd edn., Bethany House Publishers, Bloomington.

Goudriaan, A., 2011, 'The Synod of Dordt on Arminian anthropology', in A. Goudriaan and F. van Lieburg (eds.), Revisiting the Synod of Dordt (1618-1619), pp. 81-106, Koninklijke Brill NV, Leiden. (Brill's series in Church History, vol. 49).

Heitink, G., 1999, Practical Theology - History, theory, actions fields, Eerdmans, Grand Rapids.

Immink, G., 2008, 'Een methode van preekvoorbereiding', in $\mathrm{H}$. van der Meulen (red.), Als een leerling leren preken - Preekvoorbereiding stapsgewijs, pp. 9-20, Uitgeverij Boekencentrum, Zoetermeer.

Latham, A.A., 2011, 'Theorizing the Crusades: Identity, institutions, and religious wars in medieval Latin Christendom', International Studies Quarterly 55(1), 223-243. http://dx.doi.org/10.1111/j.1468-2478.2010.00642.x

Lundblad, B.K., 2001, Transforming the stone - Preaching through resistance to change, Abingdon, Nashville.
McMickle, M.A., 2006, Where have all the prophets gone? Reclaiming prophetic preaching in America, The Pilgrim Press, Cleveland.

Müller, J., 2006, Opstanding, Lux Verbi, Wellington.

Pleizier, T., 2010, Religious involvement in hearing sermons - A grounded theory study in empirical theology and homiletics, Eburon Academic Publishers, Delft.

Rebel, J.J., 1981, Pastoraat in pneumatologisch perspektief, Kok, Kampen.

Reiss, M.J. \& Straughan, R., 1996, Improving nature? The science and ethics of genetic engineering, University Press, Cambridge.

Rheeder, A.L. \& Vorster, J.M., 2006, 'Genetiese manipulasie as selektiewe voortplanting - 'n Voorlopige teologies-etiese beoordeling', In die Skriflig/In Luce Verbi 40(1), 131-153. http://dx.doi.org/10.4102/ids.v40i1.336

Sandel, M.J., 2009, The case against perfection: Ethics in the age of genetic engineering, Harvard University Press, Harvard.

Sinnema, D.W., 2011a, 'Calvin and the Canons of Dordt (1619)', Church History and Religious Culture 91(1/2), 87-103. http://dx.doi.org/10.1163/187124111X557782

Sinnema, D.W., 2011b, 'The Canons of Dordt: From judgment on Arminianism to confessional standard', in A. Goudriaan \& F. van Lieburg (eds.), Revisiting the Synod of Dordt (1618-1619), pp. 313-334, Koninklijke Brill NV, Leiden. (Brill's series in Church History, vol. 49).

Tubbs Tisdale, L., 2010, Prophetic preaching - A pastoral approach, Westminster John Knox Press, Louisville.

Van Ruler, A.A., 1969, Structuurverschillen tussen het christologische en het pneumatologische gezichtspunt (Theologisch Werk 1), Callenbach, Nijkerk.

Whitehead, A.N., [1926] 1941, Process and reality: an essay in cosmology, Social Science Bookstore, New York.

Wogaman, J.P., 1998, Speaking the truth in love - Prophetic preaching to a broken world, Westminster John Knox Press, Louisville. 